УДК 821.163.41.09 Гундулић. И. https://doi.org/10.18485/msc50.2019.1.ch44

\title{
Силија Хоксверт
}

\section{ГУНДУЛИЋЕВЕ СУЗЕ СИНА РАЗМЕТНОГА У СВЕТЛУ ЕНГЛЕСКИХ ПЕСНИКА МЕТАФИЗИЧАРА}

Насловом овог реферата не бисмо хтели да сугеришемо да је могуће да у Сузама сина разметнога видимо „метафизичку” песму у смислу у којем се овај термин обично употребљава у односу на одређену групу енглеских песника седамнаестог века. Напротив, циљ овог рада је покушај да се песма ослободи уобичајених оквира како би се сагледала у новом светлу. Два есеја посвећена делу, и разне историје хрватске књижевности, ${ }^{1}$ утврдили су контекст у којем се песма обично разматра. Укратко, може се рећи да постоје две главне тачке приступа: ранији, компаративни приступ Шрепела, где се дело упоређује нарочито са Тансиловим делом La Lagrime di San Pietro, и стилистички приступ по коме се дело описује низом епитета као што су „извештачено”, „накићено”, а који се сви могу укључити под сада опште употребљаван термин „барокни”. Ни Шрепел, ни Водник нису употребили овај термин, али је њега установио Комбол, који га је употребљавао у изворном, мање-више потцењујућем смислу. 2 У новијим студијама овог раздобља термин се употребљава једноставно да опише превладајући стил хрватске и српске књижевности седамнаестог века, и као такав, термин се већ потпуно усталио. Без обрзира на то, чини нам се да би могло бити корисно да песму посматрамо из потпуно друкчије перспективе, тако што ћемо је посматрати у контексту енглеске метафизичке поезије. Надамо се да ћемо на тај начин моћи да у њему видимо одређене преокупације и претпоставке које су биле заједничке

${ }^{1}$ M. Šrepel: O Gundulićevim „Suzama sina razmetnoga”, Rad JAZU, knj. 127, 1896; A. Haler: O Gundulićevim „Suzama sina razmetnoga”, Hrvatska revija, god. XI, br. 12, 1938; B. Vodnik: Povijest hrvatske književnosti, 1913; M. Kombol: Povijest hrvatske književnosti do preporoda, 1945; F. Švelec u Povijesti književnosti u 7 knjiga, knj. 1974.

2 Vidi R. Wellek: Concepts of Criticism, New Haven, 1963, стр. 69-127. 
целој европској набожној поезији, као и неке црте које су специфичне за европску књижевност седамнаестог века.

Термин „барокни” је свакако проблематичан. Испоставља се да постоје два начина на које се може корисно употребљавати, али чињеница да оба постоје и даље спречава да се један од њих коначно прихвати. Као што је познато, термин се најпре употребљавао у историји уметности, да би описао одређен стил који карактеризује европску уметност између ренесансе и неокласицизма. ${ }^{3}$ Чињеница да се термин најпре употербљавао у односу на визуелну уметност, и да се тек касније пренео и на књижевност, вероватно донекле објашњава варијације у употреби термина. Он се употребљава на разне начине у односу на поједине националне књижевности. Шире узето, међутим, ове варијације још увек одражавају основну дилему - да ли би требало да се термин употребљава као опис одређеног стила, у смислу „украшен”, „претрпан”, „усклични”, „емотиван”, или, пак, да одреди читаво историјско раздобље. У уводу свога недавног рада, ${ }^{4} \mathrm{~F}$. J. Warnke дао је користан приказ читавог низа научних радова који су се у двадесетом веку на разним језицима бавили овим питањем. Warnke ce сам опредељује за ширу употребу: у свом раду, он упо-требљава „барокни” да опише заједничке црте европске књижевности, њој специфичне, у односу на ренесансу с једне стране и неокласицизам с друге. Пошто Warnke одређује раздобље које покрива овај термин - 1580-1690. - он га више-мање употребљава као синоним за „седамнаести век”. Он сматра да ће термин вероватно добити сличан широки значај као и „романтизам”, термин који, као што знамо, дозвољава велику ра-зноврсност. Тек треба да се види хоће ли термин „барокни” моћи да се коначно ослободи неких одређених асоцијација код многих критичара и историчара књижевности, и да се устали у овако широкој употреби. За сада, чини нам се да је могуће расправљати о томе да ли појам „седамнаести век” сам по себи не укључује све што би професор Warnke хтео да унесе у свој широки термин. Међутим, како је неопходно да се што јасније и тачније одреде одлике, преокупације и претпоставке тога раздобља, чини нам се да се овај циљ не може у потпуности постићи ако се употребљава појам који је већ прихваћен и у ужем значењу. У оквиру заједничких особености књижевности седамнаестог века, ипак се ра-зликује известан број различитих стилова. Међу њима има један који је у америчкој и енглеској критици добио разне називе: „барокни”, „високо-барокни”, „манерист”.

\footnotetext{
${ }^{3}$ H. Wolfflin Renaisance und Barock, München, 1888.

${ }^{4}$ F. J. Warnke: Versions of Baroque, New Haven, 1972.
} 
Биће потребно овде да покушамо укратко да размотримо неке од заједничких претпоставки које се налазе у европској поезији седамнаестог века уопште, а у набожној поезији посебно, како бисмо могли да ове претпоставке онда потражимо у Гундулићевим Сузама сина разметнога. Исто тако, мораћемо идентификовати неке од посебних одлика стила који се назива „барокни”, како бисмо могли да видимо до које мере се ове црте могу наћи у Гундулићевом делу. Хтели бисмо да сугеришемо да се, иако су Сузе сина разметнога неоспорно дело седамнаестог века, за разлику од ренесансе, ипак не могу сматрати „барокним делом” у уској дефиницији термина.

У својој одличној, сажетој студији The European Background to Baroque Sensibility, ${ }^{5}$ Odette de Mourgues каже да смо сада навикли да мислимо на касну ренесансу као неку врсту „сrise de conscience” у Европи, и ово прелазно доба све више привлачи савремену критику као раздобље у којем „се нешто од велике важности дешавало у европском уму”. Чињеница да нас овим речима Mme. de Mourgues подсећа на познату студију Т. С. Елиота о енглеским песницима метафизичарима, ${ }^{6}$ један је од фактора који су нас охрабрили да покушамо да овим радом допринесемо тумачењу ове теме. Разлози опште кризе су веома познати: утицај ренесансе и реформације на средњовековни свет хришћанства; сукоб између католика и протестаната; политичка несигурност и верски ратови; доминација „нове науке” која је човека избацила из средишта свемира. Ово расположење се јасно наговештава у познатим стиховима енглеског песника, John Donne:

And new Philosophy calls in doubt, The Element of fire is quite put out; The Sun is lost, and thearth, and no man's wit Can well direct him where to look for it. ${ }^{7}$

Књижевност ренесансе била је сва посвећена реалности видљивог света, и доживљаји чула су се славили са радошћу и заносом. Сви су веровали у хармоничну равнотежу између две разине стварности - тела и духа. У новом раздобљу опште сумње, као да се стварност растворила на разне неповезане делове. Познати средњовековни сукоб између духа и чула претвара се често у претерану превагу или једног или другог. Једна

5 y The Pelican Guide to English Literature, vol. 3: From Donne to Marvell, 1956, str. 89-97.

6 The Metaphysical Poets, Times Literary Supplement, 1921. U y Selected Essays, 1932.

7 John Donne, The First Anniversarie, 1611. 
од главних тема прве половине седамнаестог века је збрка стварности и илузије. На овај начин се одражава основни немир који је довео до тога да се на живот гледа као на слику, позорницу, сан. ${ }^{8}$ Једна последица такве сумње у стварност довела је до опште склоности писаца седамнаестог века, који су писали о љубави или о религији, не да набрајају лепоте вољене, или да певају химне у славу божје свемоћи, већ да се усредоточе на разматрање мистерије саме љубави, или односа човека према своме Богу. Даља последица овог доживљаја живота као сукоба супротности, исто тако је општа склоност да се ова борба изражава као сукоб између човекове личности и вањског света, што је довело до расцвата драмских лирских песама у европској књижевности седамнаестог века, од којих је врло значајан број набожан. Ове песме приказују напете драматичне ситуације у којима се сукобљавају или Бог са душом, или душа са неком утеловљеном апстракцијом, или супротни аспекти душе, или неке друге dramatis personae које се пројектују из унутрашњих доживљаја. Као што каже Warnke: „У религиозној поезији седамнаестог века, не слушамо говор, него га прислушкујемо - сам говор је упућен Богу или неком аспекту говорникове личности. Однос читаоца према песми је, онда, тачно однос публике према драми."

То су, дакле, неке опште црте књижевности седамнаестог века које се могу следити кроз разне стилове. Мада, наравно, има још много чега о чему би се могло говорити, ипак за детаљније разматрање појединих тема неопходно је да се идентификују разни стилови како би се разликовали један од другог. Притом се мора рећи да се енглеска метафизичка поезија истиче као нешто изузетно у европској књижевности седамнаестог века. Ови песници су се суочили са сумњом и немиром који се изражавају у Donneovoj песми, и постигли су зачуђујућу равнотежу између емоција и разума. Не можемо овде да улазимо у посебне разлоге за њихово постигнуће, а разуме се да не би требало да очекујемо такву равнотежу у поезији песника као што је Гундулић. Међутим, појавило се неколико студија у последње време које теже за тим да показују како постоји једна „европска метафизичка поезија”. ${ }^{10}$ Mazzeov рад показује да се основа поступка енглеских песника метафизичара налази у књижев-

8 Ово се може видети у немачкој, француској и енглеској књижевности и, дакако, у познатој драми Calderóna: La vida es sueño.

9 Op. cit., стр. 137.

${ }^{10}$ Odette de Mourgues: Metaphysical, Baroque and Précieux Poetry, Oxford, 1953; F. J. Warnke: European Metaphysical Poetry, New Haven, 1961 (антологија); J. А. Mazzeo: A Seventeenth Century Theory of Metaphysical Poetry y Rennaissance and Seventeenth Century Studies, New York, 1964. 
ној теорији Graciána и разних италијанских теоретичара. Ова се теорија ослања на појам „ingegno”. Док је књижевна теорија ренесансе тврдила да је уметност имитација природе, прави уметник седамнаестог века био је тај који је могао да природу преобликује својим умом, деловањем „ingegno” или „wit”.

У својој антологији Warnke показује да је оно што он зове „метафизичка варијација барокног стила" било заправо једна шира појава, заједничка француским, холандским, немачким и појединим италијанским и шпанским песницима. Међу поступцима ових песника, осим „concetto” који је производ „ingegno”, Warnke наводи парадокс и иронију који су у присној вези са „concetto”, по томе што пажњу усредоточују на противречну природу људских доживљаја у тежњи да се дође до скривене истине. Warnke наглашава темељно интелектуалну природу средишње традиције енглеске метафизичке поезије коју je Eliot назвао „tough reasonableness”, а коју je Grierson ${ }^{11}$ описао ко „чудна мешавина страсти и мисли, осећања и разума". У овој поезији, у којој преовлађују аргументације о бити, разликама и разлозима, песничке слике се нужно упо-требљавају као дијалектичко средство и нипошто нису украс, него битна карактеристика методе.

Најснажнији утисак који оставља читање већег броја енглеских песника метафизичара је сукоб. Штиво им је тешко, захтева концентрацију од стране читаоца и уверавање и доказе од стране писца. То је у бити „мисао у процесу формације", 12 а не мисли које већ постоје и које се стављају у већ постојеће форме. У речима Helen Gardner ${ }^{13}$ у процесу доминације штива, средства питања, парадокса и негације служе да пренесу утисак борбе, сукоба. Битно је да штиво никада не надвлада песника, ма колико страсну емоцију да он савлађује или обуздава. Нити „сoncetto” не губи додира са сврхом у којој је употребљен.

Ово питање савладавања, равнотеже, свакако је карактеристична црта метафизичке поезије у односу на други ток седамнаестог века који би требало сада укратко да размотримо, ток који многи критичари називају барокном поезијом. Од свих италијанских теоретичара „ingegno”, jeдини је Tesauro скренуо пажњу на опасност која је својствена „concetto": по својој природи, без дисциплине, „ingegno” неизбежно води претери-

${ }^{11}$ Herbert J. C. Grierson, увод у Metaphysical Lyrics and Poems of the Seventeenth Century, Oxford, 1921.

12 Види Warnke: Versions of Baroque, стр. 41 где спомиње Montaignea у овом погледу.

13 Увод у антологију The Metaphysical Poets, Penguin Books, 1957, стр. 22. 
вању. ${ }^{14}$ Недостатак равнотеже је, као што смо видели, чешћи одјек касне ренесансе - савршена уравнотеженост која је велики домет поезије Donnea, Herberta и Marvella, веома је деликатна, и сасвим је разумљиво да се често руши, или не постиже, или да се песник чак и не труди да је постигне, тако да већина поезије тог раздобља пре одражава изопачену слику живота. Ову врсту поезије карактерише преовладавање чула, било привлачних било одбојних, дислокација, дезорганизација. Она је чешће дескриптивна него рефлексивна и пружа нагле контрасте.

Као закључак овог излагања унели бисмо цитат из дела Mme de Mourgues где она покушава да опише разлику између ова два стила:

„In metaphysical poetry we judge a poem by the art with which the poet achieves the reconciliation of clashing opposites. In baroque we should judge a poem by the art with which the poet expresses the experiences of a sensibility determined to go, unchecked, to the bitter end of its reactions to the problems of the age.

The baroque poet thus depends on his power to carry his reader into his own world which is often a sort of surreality, and to light up for him those strange vistas which such baroque sensibility can open up both in the concerete world of nature and in the recesses of a man's consciousness. Accordingly the stylistic devices used by the baroque poet will work mostly on the imagination and the emotions of the reader, and as powerfully as possible. Hence, perhaps, that impression of violence, restlessness, or vehemnce which is often linked with the term baroque." ${ }^{15}$

Ако можемо да прихватимо такву дефиницију, или неку сличну, биће нам свакако јасно да, иако можда не бисмо одмах Сузе сина разметнога сврстали под наслов „метафизичка песма”, исто тако их не можемо сматрати за „барокну песму” у овом ужем смислу. Нема места у Гундулићевој песми где се емоције не савладавају, ни емоције, ни техника песника нису ни у чему претеране. Гундулићева песма се потпуно подређује средишњој идеји и развија се систематски према своме крају.

Донекле оваква дискусија мора да изгледа вештачка, пошто су категорије које смо сада разматрали наравно биле далеке од мисли песника. Можда ће се на крају испоставити да је разлика између ових стилова заправо одраз два различита темперамента. Вероватно је, на пример, да се енглески песник за којег се обично каже да је био најближи европском

${ }^{14}$ Mazzeo, op. cit., стр. 35 где спомиње Tesauro: Il Connochiale Aristotelia Venezia, 1663.

${ }^{15}$ Odette de Mourgues: Metaphysical, Baroque and Précieux Poetry, стр. 74. 
барокном стилу - Richard Crashaw - по темпераменту осећао ближе једном неумереном начину изражавања него да се ради о директном утицају. ${ }^{16}$

Треба сада, међутим, да размотримо други ток писања седамнаестог века с којим се Гундулић најчешће доводи у везу, и ту је, напротив, његово укључење у тај ток свакако било свесно. Писао је у традицији „књижевности суза" која је била врло популарна у набожној књижевности у прози и стиху Италије, Француске и Шпаније. Ова је традиција добро позната. ${ }^{17}$

У свим овим делима не ради се о непоузданој сентименталности: тужбалица има претежно интелектуални облик. ${ }^{18}$ у песми Roberta Southwella Mary Magdalens Tears, на пример, утисак теолошког начина размишљања је јасан у питањима, одговорима и аргументима од којих се саставља дијалог.

Овде нећемо моћи детаљније да размотримо питање колико Гундулић дугује Tansillu. ${ }^{19}$ Довољно је сада да кажемо да се Сузе сина разметнога разликују од Le Lagrime di San Pietro у неким битним погледима. Нема сумње да је Tansillovo дело било шире познато и веома популарно. Међутим, требало би имати на уму чињеницу да је Tansillovo дело, или барем његова прва верзија, ${ }^{20}$ објављено 1560. године, дакле 62 године пре Суза. Tansillo сам доста јасно припада ренесенси, иако се може рећи да његов стил донекле наговештава неке од претераности седамнаестог века, и ово би могло да објасни његову велику популарност. ${ }^{21}$

16 Верска припадност је свакако деловала на његов стил после његовог обраћања католичанству 1645.

17 Valvasone, Le lagrime della Maddalena, пре 1580; Giuseppe Policreti; La conversione di Maddalena, 1588; Giovanni Ralli: Le lagrime di Santa Maddalena, ускоро после 1588; Torquato Tasso, Stanze... per le lagrime di Maria Vergine Santissima, 1593, Nuova raccolta di Lagrime, 1593. После ових су се појавила дела на француском, шпанском и енглеском језику на тему Марије Магдалене, Tansillova песма је на исти начин инспирисала имитације на тему Светог Петра на свим овим језицима.

18 Види Pierre Janelle: Robert Southwell the Writer, New York, 1935, стр. 190.

19 Ово је заправо предмет Шрепеловог есеја, иако се не би могло рећи да је тема исцрпљена овим радом.

${ }^{20}$ Цела песма је објављена тек после песникове смрти. Претпоставља се да је песму написао као окајање после младалачког дела Vendemmiatore, које је стављено на Индекс.

${ }^{21}$ Нешто од ове популарности се види у чињеници да је чак François Malherbe написао једну од француских верзија песме, 1587. 
За сада, међутим, хтели бисмо да укратко размотримо верзију Tansillove песме коју је написао енглески песник Robert Southwell: Saint Peter's Complaint (Тужаљка Светог Петра). ${ }^{22}$ Ова је песма врло уско повезана са својим узором: чини се заправо да је настала из директног превода изворног одломка који се појавио још $1539 .{ }^{23}$ Сам превод никад није објављен, али изгледа да је током рада на њему Southwella погубљена, 1595. Tansilova песма, како је познајемо у њеној потпуној верзији објављеној 1585, прилично је опсежно дело које се састоји од петнаест певања, углавном наративних, те се знатно разликује од Southwellove верзије која је написана искључиво у првом лицу и у којој нема ни једног јединог наративног одломка. Southwellova песма одражава оно својство набожне поезије седамнаестог века које смо забележили већ у почетку: изравну комуникацију између душе, која је овде утеловљена у специфичној особи, и њеног Бога.

Robert Southwell провео је девет година у Риму - од 1577. до 1586. - где је заређен за исусовачког свећеника 1584. Та последња четврт шеснаестог века била је сведоком великог процвата уметности потакнутог противреформацијом. Кад ce Southwell 1586. вратио у Енглеску као мисионар, прихватио се посла да реформира енглеску поезију, која је по његовом суду била јалова и опседнута световном љубављу. Свесно се прихватио тог задатка у светлу уметности која је тада цветала у Европи: прилагођавањем метода световне поезије служења Богу. Доследно томе, Southwell jе први значајни писац нове врсте енглеске поезије у седамнаестом веку, поезије која је у својем највећем домету спојила побожност с елизабетанском лириком. Једно од првих дела, у којем је та намера у пракси остварена, је његова Saint Peter's Complaint. Не можемо овде да се упустимо у детаљну анализу односа између Southwellova и Tansillova дела, ${ }^{24}$ али ако се појединости у којима ce Southwellova песма разликује од свога узора испитају у светлу његовог исусовачког образовања, постаје одмах јасно да ce Southwellova статична тужбалица у првом лицу на посве специфичан начин разликује од Tansillova наративног дела које се креће од тачке до тачке. Southwellovo дело одражава процедуру савреме-

22 Saint Peters Complaint, with other Poemes, London 1595.

${ }^{23}$ Види: Mario Praz, Robert Southwell's „Saint Peter's Complaint” and its Italian Source, Modern Language Review, vol. XIX, 1924, no. 3.

24 Ово је већ и направљено: Praz, op. cit.; и Martz у глави књиге, The Poetry of Meditation, која се односи на Southwella. 
них расправа о медитацији по којој се Петрова тужаљка мора прихватити као прилика за изражавање личног кајања. ${ }^{25}$

Желели бисмо овде сугерисати да су управо те изваредно популарне расправе о медитацији, које су (као што је више научника већ доказало) ${ }^{26}$ необично плодно утицале на европску набожну поезију у седамнаестом веку, послужиле и као узор и оквир за дело Сузе сина разметнога.

У свом изванредно занимљивом и исцрпном приказу поезије медитације, Louis Martz полази од хипотезе да се, (ако се може доказати да је процедура медитације одиграла темељну улогу у развоју оних облика којима се двадесети век диви у делима метафизичких песника) ти песници могу проматрати не као „Donne и његова школа” већ као група писаца веома различитих по нарави и погледима, али повезаних сличностима које су углавном резултат уобичајеног провођења одређених метода верске медитације. ${ }^{27}$ Са те премисе Martz следи „медитативну традицију” у енглеској поезији седамнаестог века која је нашла свог првог истакнутог представника у Robertu Southwellu.

Снажна струја методичне верске медитације сазрела је у Европи средином шеснаестог века. Прва важна тачка у њеном развоју је папинско одобрење Духовних вежби Игнација Лојоле, 1548. Потакнуте противреформацијом и настојањима исусовачког реда, расправе о медитацији почеле су да се појављују у великом броју: по њиховој популарности по читавој Европи могло би се закључити да су одговарале темељној потреби у духовном животу европских народа, без обзира на њихову верску припадност. Медитација није била мистична активност, већ је сматрана делом духовних дужности сваког човека у његовом свакидашњем животу. У току шеснаестог и седамнаестог века, медитација је сматрана као битна вежба за провођење „доброг живота”. Martz истиче да чак и у случајевима где садржај једне песме није набожан, концентрирана аргу-

25 Види: Martz, op. cit., стр. 194 за детаљно излагање упутстава Puentea за процедуру медитације на тему Светог Петра. Puenteovo дело Meditations upon the Mysteries of our Holie Faith је објављено тек 1619. у Енглеској. Southwell je очигледно добро познавао ову процедуру јер се јасно одражава у његовом делу.

${ }^{26}$ Helen Gardner: увод у Divine Poems Johna Donnea, 1952; L. L. Martz: The Poetry of Meditation, New Haven, 1962; E. M. Wilson: Spanish and English Religious Poetry of the 17th century y Journal of Ecclesiastical History, 6p. 9, 1958, стр. 38-53.

${ }^{27}$ Martz, op. cit., стр. 2. 
ментативна природа енглеске поезије седамнаестог века показује снажан утицај дисциплине медитације - толико се та пракса проширила. ${ }^{28}$

Пре него што се упустимо у разматрање облика медитативних вежби и анализе Суза сина разметнога с овог гледишта, морамо споменути још један утицај у духовном животу тог раздобља: тенденцију испитивања самога себе и упознавања самога себе, тенденцију која потиче још из касног средњег века, а која је досегла кулминацију у необично популарној расправи: дело под насловом Духовна борба (Combattimento Spirituale) које се приписује Lorenzu Scupoliu, објављено први пут $1589 .{ }^{29}$ Ово дело може се прихватити као друга важна тачка у развоју свакодневног духовног живота лаика у току седамнаестог века. Ово дело посебно истиче потребу вежбања духа да „брижљиво надзире чула” и да разликује „оно што је видљиво оку од онога што се може видети само духом”. У складу с тим наглашавањем анализе властитог ја, издање Exercitia spiritualia, објављено у Риму 1609, препоручује укључење медитације о разметном сину у вежбе препоручене за прву недељу медитативне праксе. ${ }^{30}$ Кајање сина разметнога је тема коју је уопште потицала читава атмосфера противреформације, премда се још увек по популарности није могла мерити с темом Светог Петра и Марије Магдалене.

У свим многобројним расправама о медитацији има уочљиве сличности поступка која је очигледно последица веома раширеног утицаја Лојолиних Духовних вежби. Прва је чињеница од битне важности та да пракса медитације мора укључити „три силе душе”: памћење, схватање и вољу. Оне представљају три ступња напретка према коначним циљевима „похвале” и „службе” Бога. Комплетна медитација се састоји од припремне молитве, неколико увода, три до пет главних тачака и колоквија у којем се медитатор изравно обраћа своме Богу. Први увод је позната „композиција места”. ${ }^{31}$ У теорији медитације битно је служити се способношћу духа да ствара слике да би се створила конкретна и жива сцена за медитирање о невидљивоме. То укључује свесно и интензивно усредоточење духа и мисли на строго омеђено подручје. У другом уводу износи се оно што медитатор жели постићи у целокупној вежби: предвиђен је коначан циљ и зацртан је специфични пут којим ће се медитација кретати

28 За шире импликације ове теме, у односу на Yeats, Wallace Stevens $i$ Coleridge види Martz, op. cit., стр. 67-68.

29 Combattimento Spirituale, види Martz, стр. 118.

30 Види Directorium Исусовачког реда, глава 14, члан 1; Exercitia Spiritualia, глава 15, члан 4, Roma 1609.

31 Нпр.: Donne: good Friday 1613, Riding Westward; Crashaw: To the Name, above Every Name; Vaughan: I walkt the other day (to spend my hour). 
према свом завршетку да би се то држало на уму у току целе вежбе и на тај начин осигурала максимална концентрација. Посебно је важно да то кретање укључује све три силе душе. Кад су се једном три силе на тај начин интегрирале медитацијом, постигнут је врхунац и циљ вежбе, и душа је, преображена, понесена увис да разговара с Богом и да чује Бога како се њој обраћа. ${ }^{32}$ Потпуна медитација може се стога природно поделити у три дела: композиција, анализа, разговор.

У закључку свог излагања методе медитације професор Martz истиче како интелектуална схема целе вежбе не твори природно сама по себи штиво поезије, али да се фрагменти целине често обликују у песме. То се најчешће уводи у колоквиј: тренуци најинтензивнијег поштовања и дивљења. То се очигледно може применити на краће песме којима су енглески метафизички песници били склони, премда се код многих може закључити да прате целокупну вежбу у згуснутом, језгровитијем облику.

Овај дужи увод био је потребан пре него што се усредсредимо на Сузе сина разметнога и размотримо не би ли нас брижљива и чврста композиција ове песме могла навести на помисао да је Гундулић сигурно добро познавао праксу медитације (вероватно се чак и њоме бавио), будући да је била толико популарна и раширена у његово доба. У његовој породици је било неколико свештеника, а међу њима и исусоваца, и у његову кућу су често залазили и исусовци из Италије. У сваком случају, његова се песма може без икаквог напора интерпретирати у складу са праксом медитације.

Прво што нам пада у очи код те песме је чињеница да је подељена на три дела. Tansillove Le Lagrime di San Pietro не држе се тако крутог узора - њена се коначна верзија састоји од петнаест певања, а раније од тринаест „pianti”. Могло би се рећи, међутим, да Гундулићева три дела тачно одговарају „трима силама душе”: Сагрјешеюе памћењу, Спознаюе схватању и Скрушење вољи. Та су три појма заправо изиричито евоцирана, као што ћемо видети кад детаљније размотримо сваки део песме.

У првој критици налазимо несумњиво стилизовано, али упркос томе концентрисано изношење неких битних елемената целе песме: изравна изјава у првом лицу, експлицитна идентификација песника с његовим предметом, и идеја кајања за прошле грехе коју та идентификација имплицира:

Грозно сузим горк плач сада, горко плачем грозне сузе ке разметни син нјекада

32 Martz, cтр. 36. 
кајан з гријеха лијеват узе;

једа и моје гријехе оплачу,

сузе у сузах, плач у плачу.

Чињеница да се тај „синопсис” појављује овде, пре праве медитације, може се вероватно приписати различитим узроцима: дуготрајној традицији да се пре дела напише увод, у прози или стиху, или једно и друго, на који наилазимо у неколико класичних дела ране хрватске књижевности, од Jyдите до Планина, и која се, дакако, појављује у Tansillovim Le Lagrime di San Pietro, у којем се испред сваког canta налази Argomento у стиху и Allegoria у прози. Тиме се такође добија непосредан почетак који служи да се привуче читаочева пажња, средство које је уобичајено не само у уметничкој поезији, већ и у усменој традицији Јужних Словена. У Гундулићевој песми, другим речима, то није пуко формално средство, као што би се можда могло рећи за Tansillovu, већ има одређен уметнички циљ.

Песма као целина у упадљивој мери следи праксу медитације. Уводна молитва обухвата идуће три китице, обраћајући се редом сваком од три елемента светог тројства. Идуће четири китице творе прелудиј - који би у процедури медитације требало да следи композицију места, али овде је део увода, девијација која опет може потпуно да се оправда с уметничког становишта - разуме се, Гундулић се заправо не бави вежбом медитације већ саставља књижевно дело. Изношење идеја које ће бити представљене у песми, и које ваља држати на уму за време целог читања, те закључци који се могу извући из целог дела, укључују истицање памћења, и то посебног облика памћења какав се препоручује у Духовној борби: непрестано присећање да је спољашњи свет илузија; спознаја божанске способности праштања греха искреном покајнику и свест о смрти као светло по којему се може водити „добар живот”; 9. до 12. китица служе затим као „композиција” места. Пејзаж који је овде укратко описан упадљиво подсећа на једну Southwellovu песму:

A vale that is enwrapt with dreadfull shades,

Which thick of mourning pines shrouds from the sunne,

Where hanging clifts yeld short and dumpish glades.

And snowie floud with broken streames doth runne... ${ }^{33}$

Могло би се зато закључити да је такав метафорички пејзаж - чија суморност наравно изражава очајно стање духа скрушеног грешника - била посебно омиљена тема, или као прикладна средина за медитацију или

${ }^{33}$ A vale of teares. 
као тема саме медитације. Метафоричка природа тога пејзажа такође одражава тенденцију карактеристичну за седамнаести век - да се невидљиво учини видљивим. Гундулић се враћа свом пејзажу на неколико места у песми употребљавајући га или као супротност начина живота који је грешник изгубио, или као одраз његовог тренутног душевног стања.

Овде неће бити могуће да анализујемо детаљно сваки од три „плача”, али верујемо да таква анализа уистину показује како се сваки од њих креће врло брижљиво зацртаним путем од тачке до тачке које имају одређено место и циљ у целокупној медитацији. Заправо, ретко ћемо наићи на неко шупље вештачко средство које није оправдано својом функцијом у песми. Даћемо само два кратка примера: у првом плачу четрнаеста до осамнаеста китица износе низ супротности које редовним враћањем на изворни призор омогућују песнику да још јаче истакне алегоријску идеју свесног замењивања доброг живота за лажни. На сличан начин употреба конвенционалног „петраркистичког” парадокса у 35-ој китици оправдана је целокупним инсистирањем песника на илузији љубави; или дугачка негативна евокација понашања љубљене у 21-ој и 22-ој китици која служи да појачава дојам њеног недостатка начела.

Неколико поенти, које налазимо у песми, познате су нам из набожне поезије седамнаестог века у Енглеској. Једна од најважнијих је тема која се код Гундулића врло често понавља, тема свести о своме ја и самозаваравања, која врло јасно одражава смер размишљања изнесен у Духовној борби. Та је тема укључена у лајтмотив који се појављује у сваком плачу песме, изражена у првом као „себе у себи не видећи”. Овај се мотив провлачи кроз готово сву енглеску набожну поезију овог раздобља, а један је од најјаснијих примера Donneov стих:

Seeke wee then our selves in our selves... ${ }^{34}$

Врло важна тенденција набожне поезије седамнаестог века, повезана с тим појмом, је тенденција самоироније. То је део процеса пројектовања свога ја као драмског лика на унутарњој позорници духа и битан је за медитацију која зависи од узајамног деловања пројектованог, драматизираног дела свога ја и целог духа медитатора. Самоиронија је најуочљивија у првом делу песме где Гундулић истиче илузорни карактер материјалног света утеловљен у жени: иронична употреба конвенционалног петраркистичког идеала лепоте наступа тек после изношења његовог битно негативног аспекта. Тема достиже кулмунацију у крешченду супротности

${ }^{34}$ To Mr Rowland Woodward. 
(китице 27-32) који доводи до прекрасног уводног стиха 33. китице, драматичног преокрета након онога што јој је претходило:

Ја за ову само хајем...

Први део песме затим води кроз неколико одређених тачака да би изнео главну идеју о илузорној природи видљивог света. То дугачко изношење грешниковог упорног тражења материјалне лепоте само по себи наговештава величину напора који је потребан да се увек „памти” истинска природа света.

Други део започиње изношењем његове средишне теме: теме божанског светла које у себи спаја божанско милосрђе и људску способност „разумевања”. И та је идеја једна од кључних идеја седамнаестог века, као што је Martz доказао у својим проучавањима дела Vaughana, Trahernea и Miltona са становишта аугустинске концепције „унутарњег просветљења". Она изражава темељно уверење како је интелект човека неразориво унутарње „светло” које тежи према спознаји вођено вишим „Светлом”. Битно је у том становишту да се лик Бога не манифестује у човековом пуко пасивном поседовању одређених одлика, већ у деловању разума, у моћи да се разум употреби за своју праву сврху.

Ваљало би можда истаћи да се углавном оправдано сматра како је овај други део најлепши песнички домет целог дана. Јасно је такође да су главне идеје - пролазност материјалног света, смрт као „велики изједначитељ", и тако даље - конвенционалне идеје познате још из раног средњег века. Та познатост и присутност вероватно донекле објашњава зашто Гундулићу полази за руком да их третира с тако изванредним уметничким осећајем и сигурношћу: међутим, када наилазимо на неке замршеније мисли (у 45-ој и 55-ој китици у том делу), израз понекад постаје незграпан, одражавајући можда оскудност традиције у којој Гундулић пише, и момент у којем заказује његова знатна моћ изражавања.

Средишња тема трећег дела је тема „воље”: вечно чудо препорода, преображавања путем божјег милосрђа које се не поклања незаслужено већ се мора стећи борбом. И та се идеја појављује у енглеској метафизичкој поезији, а један од најлепших примера су красни стихови Georgea Herberta:

Who would have thought my shrivel'd heart

Could have recover'd ghreennesse? ${ }^{35}$

35 The Flower. 
Управо је у овом трећем делу наравно најуочљивија цела популарна традиција „књижевности суза” и мислимо да нећемо погрешити ако кажемо да је она углавном деловала на штету песника: он показује склоност да се упусти у конвенционалне изливе туге, на начин који сугерише готов узор. Упркос томе, осећамо степен унутарњег сукоба у немогућности грешника да се изравно обрати свом Богу све док не покуша трећи пут. У том делу, такође, парадокс заводљиве а ипак варљиве природе световне Лепоте суочен је и успешно решен појмом божанске лепоте. И та средишња идеја набожне поезије седамнаестог века овде је третирана с једноставношћу која успева да одрази истинску напетост, непатворени лични сукоб, за разлику од општијег карактера неких делова песме.

Управо у том аспекту личног суочења са централним парадоксима духовног живота појединца, Гундулић се највише приближава атмосфери енглеске метафизичке поезије. Гундулић је очигледно изменио нагласак у параболи о разметном сину како је испричана у Еванђељу по Луки. У Библији је наглашено божје праштање и враћање изгубљене овце. Гундулићева песма инсистира на личном кајању грешника у складу с духом времена и целокупном традицијом „књижевности суза”. Али тај му нагласак истовремено омогућује да изрази истинску унутарњу напетост, борбу и лични однос појединца према свом Богу, приказујући је као битно интелектуалну борбу. Управо је тај осећај интелектуалне борбе битна карактеристика енглеске метафизичке поезије и све поезије медитације.

Чини нам се да ће бити умесно да завршимо овај реферат, који толико много дугује раду професора Martza, његовим покушајем дефиниције „медитативне песме”:
„A meditative poem is a work that creates an interior drama of the mind; this dramatic action is usually... created by some form of self-address in which the mind grasps firmly a problem, or situation, deliberately evoked by memory, brings it forward toward the full light of consciousness, and concludes with a moment of illumination, where the speaker's self has, for a time, found an answer to its conflicts." 36

\footnotetext{
${ }^{36}$ Martz, The Poetry of Meditation, стр. 330.
} 


\section{C.[elia] Hawkeswort \\ GUNDULIĆ'S SUZE SINA RAZMETNOGA IN THE LIGHT OF ENGLISH METAPHYSICAL POETRY}

\section{Summary}

The paper endeavours to remove Gundulićs poem from its conventional associations with 'Baroque' literature in general and Tansillo's Le lagrime di San Pietro in particular in order to consider it in a different light. The poetry of the English Metaphysical poets manifests many of the common assumptions of Seventeenth Century European devotional poetry. A brief examination of the terms 'baroque' and 'metaphysical' attempts to show that in the light of recent criticism which has traced a European traiditon of 'metaphysical' poetry, it may not be appropriate to regard Gundulić as a 'baroque' poet in the commonly accepted narrow sense. The paper then considers Suzesina razmetnoga with regard to Tansillo's poem and the whole tradition of the 'literature of tears', and in particular with reference to the version of Tansillo's work written by the English poet, Robert Southwell. The main emphasis of the paper lies in a consideration of Suze sina razmetnoga in the light of recent work on the poetry of meditation. The partice of formal meditation, immensely popular in Europe in the seventeenth century, is described and Suze sina razmetnoga examined as an example of a meditative poem that closely follows this practice. 